ensis. Of other vertebræ from the Forest-bed, one, a caudal, was referred to Balana; another, from the lumbar region, to Balcenoptera.

The following specimens were exhibited :-

A series of Plant-remains from the Cromer Forest-bed, exhibited by Clement Reid, Esq., F.G.S.

Specimens from the Shell-beds in British Columbia, exhibited by G. W. I amplugh, Esq., in illustration of his paper.

Specimens from the "Forest-bed," exhibited by James Backhouse, Esq., and E. Tulley Newton, Esq., in illustration of their papers.

\title{
CORZFSPOINDEINCE.
}

\section{ON THE DISTRIBUTION OF HIPPOPOTAMUS AMPHIBIUS.}

SIR,-I have lately read with great pleasure Dr. Henry Woodward's interesting and instructive article, on " Recent and Fossil Hippopotami," published in Dec. III. Vol. III. 1886, pp. 114-118, of this MAGazine. In that paper, Ur. Woodward assigns to the two species of Hippopotamuses the tropical or warmer parts of Africa as their present habitats. As a generalization of their present distribution, this statement may be accepted as strictly correct, but during my journeyings in South Africa, in the upland regions of Natal, the Orange Free State, and elsewhere, I was surprised to find some of the reedy "vleys" or lakes called "Leekoe Vley." Such a name is in itself evidence that the Boer immigrants, or early settlers, found Hippopotamuses in such localities; indeed, I have been informed by old settlers that such had been the case in their own knowledge, or else that the natives had told them of the former existence of the animals in such places. I have been credibly informed that 50 years ago Hippopotamuses were abundant in the Umzinduzi river, close to where now the city of Pietermaritzburg in Natal is built. The fact of these animals having inhabited localities in the uplands of Natal, and the Free State, is I think beyond question, and as those districts are at times subjected to very inclement weather, it raises the question whether the Hippopotamus amphibius is not capable of enduring far greater changes of temperature than is usually supposed. I was encamped in the vicinity of Newcastle, Natal, on the borders of the Transvaal, in the winter of 1881 (i.e. the summer of our northern hemisphere), and we experienced very severe weather. Water froze in the buckets left outside the tents at night, the snow lay deep over the country, herds of sheep and cattle were buried and frozen to death in the snow. Many farmers suffered great loss in stock. In the highlands of the Orange Free State, across the Natal border, the losses of flocks and herds from the snowstorms were greater than in Natal. The question arises, whether Hippopotamuses were denizens of these upland lakes and rivers, or only summer visitors. If residents, they must have been subjected at times to extraordinary changes of climate. I regret that during my residence in South Africa, I did not pay more attention to this interesting subject. 
I venture to send you this communication in the hope that it may attract the attention of some naturalist in South Africa, of greater experience than myself, as the subject is one of considerable interest to the geologist.-I am, Sir, your obedient servant,

WrLls, Norfolk, 2nd April, 1886.

H. W. FEILDEN.

\section{DISCOVERIES IN THE PUNJAB SALT-RANGE.}

Sir,-Since the abstract of my paper to the Royal Geol. Soc. of Ireland on the subject of Dr. Warth's discoveries in the Eastern Salt-range appeared in the Geological Magazine for March, a paper on the same subject by Dr. Waagen, of Prague, in the Records of the Geol. Survey of India (vol. xix. pt. 1), has reached me. Several points in this paper relate to the stratigraphy of the Saltrange as interpreted in my Geological Survey Report, and one or two especially touch portions of my paper referred to, and its abstract.

With reference to these last, I may notice that certain of the fossils to which I alluded as undetermined have now been fully described by Dr. Waagen, and are referred to the Carboniferous, not Devonian age, as I had been informed. Beyond accepting the purely palæontological determinations of Dr. Waagen, I have little to say : he gives his evidence, describing most of the species as new or indeterminate, or requiring further comparison, and he appears to be now satisfied as to their age. Their reference to the later period tends to reduce the interest which the discovery of Devonian forms would have possessed, on account of the absence of recognizable Devonian rocks, in that or the adjacent country.

Dr. Waagen's paper, however, differs from my own in describing these fossils as having been found in concretions, not in pebbles, and as occurring in situ in the Conularia layer. Upon this point rest very extensive and important deductions, and it is one upon which some uncertainty seems to have prevailed, leading both Dr. Warth and Dr. Waagen to reconsider matters and to change their minds : hence I am glad to learn we may expect to hear further about the matter from the officers of the Geological Survey of India.

Dr. Waagen's latest announcements, as above stated, seem to date from the end of last year or the very commencement of 1886. Dr. Warth, writing to me with specimens from this layer (and some others) under date Dec. 1, 1885, strongly maintains that the fossils are not in situ, but derived, and in support of this he calls attention to one of the specimens, a single rolled fossil Conularia, which itself formed one of the pebbles of the layer. Turning to the specimens I received (and they were few), I found they consisted of fine, pale, non-calcareous sandstone, presenting no signs of concretionary structure, their smoothed surfaces intersecting the inclosed fossils, while the special example referred to has all the appearance of a once more perfect fossil detached from its matrix, abraded and rolled till its general form alone remains, with just sufficient of its original markings to show certainly what it is. Another of the same kind shows only the outer form, and greater abrasion. 